\title{
Analysis on the innovation pattern by major industry in Korea ${ }^{*}$
}

\author{
Kyoo-Ho PARK
}

\author{
Associate Professor, Department of Business Administration, Hanshin University, Osan, Korea. \\ E-mail: nkhpark@gmail.com
}

Received: November 20, 2019. Revised: December 17, 2019. Accepted: December 24, 2019.

\begin{abstract}
Purpose - This paper aims to analyze the difference of technological innovative pattern by industry.

Research design and methodology - we try to identify the major factors which can exert an effective influence on actual innovation output, utilizing the result of Korean Innovation Survey. By doing so, this work can make a comparison with Pavitt (1984) and succeeding discussion on sectoral pattern of innovation

Results - Analysis on major industry in Korea shows that there are substantial differences in terms of the source of innovation, organization-related factor, and appropriation mechanism among each industry, and differential strategy to be proper for the nature of each industry is needed. There is some variation within industries which deemed as same type of sector defined by Pavitt.

Conclusions - This analysis call for elaborate analysis on sectoral pattern of innovation, considering the change and difference of innovative environment as well as differential business strategy and way to do innovate, which is proper considering the nature of innovative pattern in each industry for successful technological innovation in Korea. At the same time, proper policy measure considering the differential pattern of technological innovation is needed.
\end{abstract}

Keywords: Technological innovative pattern, Sectoral difference, Industry, Korean innovation survey

JEL Classification Code: O3, M1.

\footnotetext{
* This work was supported by the National Research Foundation of Korea Grant funded by the Korean Government (KRF-2010-3 32-B00095).

Earlier version was presented at $8^{\text {th }}$ Globelics international conference 2010 in Kuala Lumpur, Malaysia.
} 


\section{Introduction}

Technological innovation differs in each sector. That the way and patterns of technological innovation has differential characteristics by sectors or industries is regarded as natural things these days in the community of innovation studies, seen from the discussion surrounding sectoral innovation system. These kinds of discussion make it possible to enhance the understanding on the real phenomenon of technological innovation, and further strengthen the base of effective technological innovation and innovation policy. However, even though the advancement of theoretical discussion has been done, the discussions still just remain at the conceptual analysis and the descriptive analysis on the history of specific industry and innovation, viewed from the perspective of empirical analysis.

The discussion on sectoral innovation system still has long way to go, particularly in terms of empirical analysis. One of this comes from the data availability generating from the mismatch between the industry from the Standard Industry Classification and the conceptual sector considering the characteristics of knowledge and technology. In fact, most of statistics is made utilizing the Standard Industry Classification (SIC), and within the terminology and methodology of industrial organization focusing mainly on the static analysis based on the short-term competition among extant firms.

In this paper we suggest that even though available classification of industry cannot directly consider the characteristics of knowledge which is underlying the discussion of sectoral innovation system, utilizing the data by that industry can enhance the understanding on the way to do technological innovation or technological innovation pattern by sector. Linkage with data by industry makes it possible to utilize the discussion on sectoral innovation more actively in terms of empirical analyzing.

For finding out the differential characteristics of Korean industry, this paper tries to identify the differential innovative pattern by major industry in Korea, considering that most of the economic analysis is done at the dimension of industry which is defined at the level of product and its characteristics. Major industries are set as chemistry, machinery, electricity and electronics. These four industries captured around $43 \%$ of value added in Korean manufacturing sector in 2009 , functioning as core engine for Korean economic growth.

To this aim, we try to identify main factors which determine the output of technological innovation through the econometric analysis utilizing the result of Korean Innovation Survey which is done by industry. Based on this work, the family of industries featuring same factors and effect can be identified. In addition, this can form base for effective differential innovation policy and complement the present policy in Korea, which mainly focuses on market share and tries to enlarge it.

The composition is as follows. Section 2 gives brief summary of previous work, and section 3 represents the methodology used in this paper. Section 4 shows the result of econometric analysis, and lastly section 5 is concluding remarks.

\section{Theoretical Consideration}

Sectoral difference in terms of the technological innovative pattern has been major research theme since the historical work of K. Pavitt (Sectoral patterns of technical change: Towards a taxonomy and a theory, Research Policy, 1984) which tried to analyze the characteristics of technological innovative pattern differing by sectors utilizing the database of the major technology developed in the UK. Pavitt (1984) analyzed the source of technological innovation, generation and utilization of innovation, firm size and organization, and appropriation under the title of innovative pattern, and identified 4 types of sectors (supplier-dominated, scale-intensive, sciencebased, specialized supplier), which was extended with another type (information intensive sector) later.

The characteristics of each type can be summarized as follows (Pavitt, 1984; Tidd \& Bessant, 2009). For supplier dominated sector, most innovations come from suppliers of equipment and materials. Production intensive sector is divided into scale intensive sector and specialized supplier sector. In scale intensive sector technological accumulation is generated by the design, building and operation of complex production systems and products, therefore, the technological skills to exploit the economies of scale is important. In specialized supplier sectors firms provide high-performance inputs into complex systems of products of production, of information processing and of product development, in the form of machinery, components, instruments and software, therefore, the competitiveness depends on firm-specific skills reflected in continuous improvement in product design and in product reliability and in the ability to respond to users' needs. Finally, for science-based sector the main sources of 
technology are the R\&D activities of firms, based on the rapid development of underlying sciences in the universities and elsewhere.

Inspired by this work, further conceptual work has been done by various scholars. Conceptually one of the most successful work is the formulation of sectoral innovation system (SIS) focusing on the characteristics of underlying knowledge of technological innovation, particularly its differential nature. These works study the main constituents such as technological opportunity, cumulativeness, appropriability, and the nature of knowledge base, and their relationship (Malerba \& Orsenigo, 1996; Breschi et al., 2000), considering the characteristics of knowledge.

Empirical works have three strands. The first one is to apply these types of sector in specific context, i.e. specific country, or specific group of firms in order to confirm whether these types can still hold in another context (Freel, 2003). In addition, some work suggested new taxonomy and tries to confirm its possibility (Castellacci, 2008).

Second, analysis of sectoral innovation system has been done on the individual sector on a large scale, mainly in Europe and sectoral difference is confirmed utilizing the macroeconomic data (the typical work is F. Malerba (ed.), 2004, Sectoral systems of innovation: concepts, issues and analyses of six major sectors in Europe, Cambridge university Press). In Korea, STEPI, one of the leading research group, has done analysis of SIS on individual Korean industry, and also analysis of innovative pattern by sectors utilizing US patent data (Kim, 2004, 2006; Chung, 2001; Song, 2000; Park, 2003)

Third, in order to identify the sectoral characteristics some work tries to analyze sectoral pattern of innovation which can be shared by some companies and reflected in their innovative activities (de Jong \& Marsili, 2006). This work usually utilized the method of Principal Component Analysis and cluster analysis in order to reduce the number of variables.

Due to these previous works, we can come to enhance understanding on technological innovative pattern and its difference by sectors. However, we have still a long way to go. Three points can be made, from the perspective of empirical studies in non-advanced countries. Firstly, most of statistics, related to sector, is only available at the dimension of industry, which is defined by product, not by knowledge. Second point relates to the fact that the level of innovation and the way to innovate in non-advanced countries including Korea is substantially different from that of advanced countries. Third point can be related to the changes as time goes by. Even within same sectors, the nature of knowledge can change, that is time-variant. In addition, the development of ICT knowledge and its diffusion to anther sector is rapid and can function as a momentum of transformation. With these limits, it is necessary to do empirical analysis on differential characteristics of innovative pattern by sectors in Korea, to understand the actual working of innovative activities.

\section{Methodology}

After reviewing the past work, there can be three ways to identify the sectoral characteristics of innovation pattern. The first is to build conceptual framework and make an evidence to justify this framework. Second work usually suggests the elements composing the sectoral pattern of innovation and tries to find out the sectoral characteristics using multivariate methods. Third work can be trying to find out the effective determinants in each industry.

Among these three ways, we suggest that we can identify the differential pattern of technological innovation by sectors by estimating which factors is effective by industry in term of innovative performance. This approach can be regarded as data-dependent one rather than conceptual one.

We can set influential elements on innovative performance as follows. First, source of innovation, second, the innovative organization, third, appropriation. The source of innovation is composed by source of information, acquisition of technology, and cooperative activities. Conceptually it can be assumed that each sector may feature different effective determinants in terms of each element. In terms of Pavitt's type of sector, in case of supplier dominated sector, the supplier is very important source for effective technological innovation and in case of sciencebased sector, the internal $\mathrm{R} \& \mathrm{D}$ and advanced research institute such as universities is very important source. Meanwhile, in case of scale intensive sector the internal experience and skill is the most importance source of technological innovation, and in specialized supplier sector the internal skill building and the relationship with customers is important. Therefore, we can expect that all of these three sources of innovation can be effective only for proper source for each sector.

Innovative organization is composed by firm size, the share of highly educated employees, the share of (formal) job training, and the form of R\&D organization. For organization, the access to and acquisition of the knowledge is important. The share of highly educated employees and the share of job training can capture the possible access to scientific and explicit knowledge and acquisition of explicit knowledge respectively. The form of R\&D organization 
can capture the internal relationship within their companies. Independent organization can explore deeply into technical knowledge, but other form of R\&D organization can acquire non-technical knowledge such as customer and market, and production.

In terms of Pavitt's taxonomy, it can be said that the access to and acquisition of explicit knowledge is important for science- based sector, compared to other types of sectors. In other sectors the non-technical knowledge and tacit knowledge can gain higher importance.

Lastly, appropriation mechanism is composed by one for product innovation and one for process innovation. The appropriation mechanism can be captured by the company's attitude toward utilizing patent for appropriation mechanism. Also, in this context the distinction between explicit knowledge and tacit knowledge is important.

Table 1: The Innovative Pattern

\begin{tabular}{|l|l|}
\hline \multirow{2}{*}{ Innovative pattern } & \\
\hline \multirow{4}{*}{ Source of innovation } & Source of information \\
\cline { 2 - 3 } & Acquisition of technology \\
\cline { 2 - 3 } & Cooperative activities \\
\hline \multirow{4}{*}{ Innovative organization } & Firm size \\
\cline { 2 - 2 } & The share of highly educated employees \\
\cline { 2 - 2 } & The share of job training \\
\cline { 2 - 2 } & Form of R\&D organization \\
\hline \multirow{4}{*}{ Appropriation mechanism } & Appropriation mechanism for product innovation \\
\cline { 2 - 2 } & Appropriation mechanism for process innovation \\
\hline
\end{tabular}

There can be two types of innovation surveys, which can be divided into subject approach and object approach (Smith, 2005). While Pavitt's work utilized the latter survey in UK, it is almost impossible to use it these days, and alternatively we can utilize surveys with subject approach. This kind of survey can be found in Innovation survey done by many countries these days. Korean Innovation survey done by STEPI is typical, following the Oslo manual, similar with Community innovation survey done in Europe. We utilize the Korean Innovation survey done in 2005.

Considering the amount of data, we limit our analysis to major typical industries, that is, chemical industry, machinery industry, electricity and electronics which has essential role for Korean economy. Each industry is captured by two-digit SIC cords. Their full titles are; Manufacture of Chemicals and Chemical Products (24 industry), Manufacture of Other Machinery and Equipment (29 industry), Manufacture of Electrical Machinery and Apparatuses (31 industry), Manufacture of Electronic Components, Radio, Television and Communication Equipment and Apparatuses (32 industry) according to Korean Standard industry classification.

According to Pavitt's typology, the chemical industry, electricity and electronics belong to science-based sector, and machinery belongs to specialized supplier sector. Therefore, it can be expected that chemical, electricity and electronics feature the characteristics of science-based sector and machinery features that of specialized supplier sector.

The equation for estimation is set as follows. The innovative output is set as dependent variable, and major factor which is regard as having possibility of influencing the innovative output as independent variables and the innovative effort whose proxy is R\&D intensity and firm size is set as control variables.

The share of sales of new products due to innovation is utilized for the proxy of the innovative output and independent factors are set as with Table 1, considering the Pavitt's work and the characteristics of Korean innovation survey

\section{Analysis on the technological innovation pattern by industry}

Now we can summaries the result of estimation by each industry. 
The source of innovation

The source of information consists of 24 channels. (1) Private research institutes, (2) Universities, (3) Public research institutes, (4) Non-profit organizations (Trade associations, Chamber of commerce \& industry etc.), (5) Affiliated companies, (6) Competitors in the same industry, (7) Firms in related industry, (8) Suppliers (raw materials/S.W.), (9) Suppliers (machinery /facilities) (10) Clients (11) Business service firms (technical, law, accounting, consulting etc.) (12) Employees (13) Informal networks among CEOs or CTOs, (14) Patent information, (15) Conferences (16) Journals and magazines, (17) Fairs and exhibitions (18) Newspapers, TVs (19) The Internet, (20) Procurement Dept., (21) Marketing Dept., (22) Research Dept., (23) Development Dept., (24) Production Dept. For statistical feasibility, we used the method of Principal Component Analysis (PCA) and could identify three groups which are named as research institutes, other firms, and media and internal sources.

As a result of estimation, following three facts are confirmed. Firstly, research institute is effective for enhancing technological innovation in all the industries. Secondly, other firms (including the market) are effective only in electronics industry (electronics). Thirdly, media and internal source of information is effective only in chemical industry and machinery industry.

For acquisition of technology and cooperative activities, there are 10 ways for it as follows. (1) Affiliated companies, (2) Competitors in the same industry, (3) Firms in related industry, (4) Clients, (5) Business service firms (technical, law, accounting, consulting etc.), (6) Suppliers (raw materials/components/S.W.), (7) Private research institutes, (8) Universities, (9) Public research institutes, (10) Non-profit organizations (Trade associations, Chamber of commerce \& industry etc.)

As a result of estimation on the acquisition of technology, we come to know that while the acquisition of technology from affiliated companies is effective for technological innovation in chemical industry, the acquisition from suppliers is effective in machinery industry and electricity industry and for machinery industry the acquisition from public research institutes is also effective. However, it is shown that the acquisition from the competitors in the same industry is statistically negatively effective in chemical industry and electricity industry.

Meanwhile, as a result of estimation on effectiveness of cooperative activities, the effect is known to be substantially different by industries. For chemical industry, while the cooperation with private research institutes and universities is statistically effective, the cooperation with public research institutes is negatively effective. For machinery industry, cooperative activities with competitors in the same industry, suppliers, universities and public research institutes is shown to be effective for technological innovation, but cooperation with affiliated companies and non-profit organizations is negatively effective for technological innovation. In addition, in electricity industry, even though the cooperation with firms in a related industry is effective, that with suppliers and non-profit organization shows negative signs. Lastly, electronics industry gains a lot from the cooperative activities with firms in a related industry.

The result does not fit exactly with Pavitt's typology. For source of information, all industry shows the importance of research institute such as university which is regarded as characteristics of science-based sector. Also, in case of acquisition of technology, suppliers is shown to be effective in generating innovative performance in machinery and electronics, which is regarded as characteristics of supplier dominated sector and scale intensive sector. For cooperative activities, in addition to suppliers the public research is shown to be effective in machinery industry. Further, in electricity and electronics, the horizontal linkage with other firms is represented as effective factor for innovative performance, which is not considered in Pavitt's discussion.

Innovative organization

In this part, we try to analyze the differential effect of firm size, personnel composition, job training, and the form of R\&D organization by industry.

Firstly, firm size measured by number of employees is shown to enhance significantly the product innovation and process innovation in all the industry. This can hint at the fact that for some economies dominated by large corporations like Korea, large corporations lead the technological innovation irrespective of the type of innovation.

Secondly, we investigate the effect of highly educated employees on the innovation output. The percentage of workers with at least Master's degrees is used as proxy. Usually highly-education person can be regarded as person who can have access to the explicit knowledge and scientific knowledge, and therefore, it can be used as estimating the effect of possibility of access to those kinds of knowledge on the technological innovation at that industry. As a result, we can identify that only in electronics industry the holding of high-educated personnel is effective and other industries does not show any significance. This means that the technological innovation has something to do with the explicit knowledge or scientific knowledge. 
Third point is related to second point we deal with previously. The factor of learning has some relationship with the previous experience of high education. In this case learning is limited as formal one, which is related to absorbing the explicit knowledge. The percentage of the employees which participated in the internal or external job training is used as proxy. Therefore, we come to estimate the relationship between the explicit learning and the technological innovation. According to data characteristics, the percentage is divided into higher participation (the percentage is more than 50\%), moderate participation (30\%-49\%), lower participation (20-29\%), minor participation $(10 \%-19 \%)$.

As a result of estimation, it is shown that in machinery industry and electricity industry, lower participation is effective for technological innovation, but for chemical industry and electronics industry, higher participation shows significant effect on the technological innovation. This may hint at the fact that the speed of change in technology and knowledge, necessary for effective technological innovation is much higher in chemical industry and electronics industry. Therefore, it is needed to raise the participation rate in the explicit learning for their employees.

Fourthly, we deal with the form which R\&D organization takes. In general, R\&D organization takes a form of independent $R \& D$ institute, $R \& D$ department as one of department, and irregular temporary organization. While, the first type of organization is effective conceptually in terms of the expertise of specific knowledge and concentration of their activities, the last type is effective in terms of the access to the knowledge of broad scope and communication with non-R\&D organization. The middle one represents the medium level.

As a result of estimation, the independent organization is mostly effective for technological innovation in all the industry, even though the middle type, the R\&D department also shows statistically positive effect. What is interesting is the fact that in electricity industry the last type, temporary organization is shown to be effective, and the size of coefficient is higher than that of R\&D department. This result seems to have relationship with the fact that set of independent $\mathrm{R} \& \mathrm{D}$ organization is granted special favor by law.

With this result, we can find out some interesting facts. First, the indicator having something with access to and acquiring explicit knowledge is effective only in electronics industry, but not in other industry which is assumed as science- based sector. Second, the independent R\&D institute is shown to be effective even in machinery which is regarded as specialized sector where the interaction with customer is very important.

Appropriation mechanism

Appropriation is essential for firms to do innovate continuously. It is natural to utilize different appropriation mechanism by sectors since the work of Cohen et al. In general, the appropriation mechanisms comprise formal mechanisms (1-4) and informational mechanisms (5-7) as follows. Those are, (1) Patents, (2) Utility Model (3) Industrial Design, (4) Trademarks, (5) Secrecy, (6) Complexity of design, (7) Lead-time advantage on competitors. The Korean innovation survey whose data we utilize is dividing the appropriation mechanism for product innovation and that of process innovation.

As results on the effect on product innovation, it is shown that patent is significantly effective in all the industries. However only for chemical industry, lead-time advantage on competitors is shown to be effective mechanism for technological innovation at the same time. Meanwhile, for process innovation, there are no significant mechanisms for machinery industry and electricity industry. However, the industrial design rights are effective in electricity industry and for chemical industry, patent rights, design rights as well as lead-time advantage is shown to be effective for technological innovation.

As a whole, a patent is effective as an appropriation mechanism in all industry for product innovation, which is expected from Pavitt's discussion.

\section{Concluding Remarks and Discussions}

This paper tries to analyze the regularity in technological innovative activities by industry and confirm the differential nature of it by industry. This is done by estimating the statistical effect of major factors on the innovation output utilizing the result of Korean Innovation Survey investigated by standard industry classification.

Major findings can be summarized as following $<$ Table $2>$.

We can summarize the typical points for each industry. Firstly, the acquisition of technology from affiliated companies is important and to pursue lead-time advantage on competitors in reaction to change of market environment is important for chemical industry. Secondly, while the internal information is not effective, but rather information from research institute is effective, likewise, acquisition of technology from outside channel is not effective but the cooperation with other firms in a related industry is important for technological innovation for electricity industry. Thirdly, the supplier is important and process innovation in addition to product innovation is 
important for machinery industry. Lastly for electronics industry it is needed to cooperate with other firms in a related industry, to recruit the highly educated personnel and to implement continuous job training.

Table 2: differential pattern of technological innovation by industry (effective factors)

\begin{tabular}{|c|c|c|c|c|}
\hline & $\begin{array}{l}\text { chemical industry } \\
\text { (24 industry) }\end{array}$ & $\begin{array}{l}\text { machinery industry } \\
\text { ( } 29 \text { industry) }\end{array}$ & $\begin{array}{l}\text { electricity industry } \\
\text { (31 industry) }\end{array}$ & $\begin{array}{l}\text { electronics industry } \\
\text { ( } 32 \text { industry) }\end{array}$ \\
\hline Source of information & $\begin{array}{l}\text { Research } \\
\text { institute/media } \\
\text { and internal } \\
\text { source }\end{array}$ & $\begin{array}{l}\text { Research } \\
\text { institute/media and } \\
\text { internal source }\end{array}$ & Research institute & $\begin{array}{l}\text { Research } \\
\text { institute/media and } \\
\text { internal source }\end{array}$ \\
\hline $\begin{array}{l}\text { Acquisition of } \\
\text { technology }\end{array}$ & $\begin{array}{l}\text { Affiliated } \\
\text { companies }\end{array}$ & $\begin{array}{l}\text { Suppliers/public } \\
\text { research institute }\end{array}$ & & suppliers \\
\hline Cooperative activities & $\begin{array}{l}\text { Private } \\
\text { research/universit } \\
\text { ies }\end{array}$ & $\begin{array}{l}\text { Competitors/suppli } \\
\text { ers/universities/pu } \\
\text { blic research } \\
\text { institutes }\end{array}$ & $\begin{array}{l}\text { firms in a related } \\
\text { industry }\end{array}$ & $\begin{array}{l}\text { firms in a related } \\
\text { industry }\end{array}$ \\
\hline Firm size & Large corporation & Large corporation & Large corporation & Large corporation \\
\hline $\begin{array}{l}\text { Share of highly } \\
\text { educated workers }\end{array}$ & Not effective & Not effective & Not effective & effective \\
\hline $\begin{array}{l}\text { Percentage of job } \\
\text { training }\end{array}$ & $\begin{array}{l}\text { Higher } \\
\text { participation }\end{array}$ & $\begin{array}{l}\text { Lower } \\
\text { participation }\end{array}$ & Lower participation & Higher participation \\
\hline $\begin{array}{l}\text { Form of R\&D } \\
\text { organization }\end{array}$ & $\begin{array}{l}\text { Institute/departme } \\
\text { nt }\end{array}$ & $\begin{array}{l}\text { Institute/departmen } \\
\mathrm{t}\end{array}$ & $\begin{array}{l}\text { Institute/temporary } \\
\text { organization/depart } \\
\text { ment }\end{array}$ & Institute/department \\
\hline $\begin{array}{l}\text { Appropriation for } \\
\text { product inno. }\end{array}$ & Patent/lead-time & patent & patent & patent \\
\hline $\begin{array}{l}\text { Appropriation for } \\
\text { process inno. }\end{array}$ & $\begin{array}{l}\text { Patent/design/lea } \\
\text { d-time }\end{array}$ & & design & \\
\hline
\end{tabular}

This discussion does not fit exactly with Pavitt type discussion on sectoral pattern of innovation. There is some variation within industries which deemed as same type of sector defined by Pavitt. Some industry features mix of characteristics of each type of sector. There can be two reasons. The first is the change of innovation environment due to time shift. Second is the differential environment of non-advanced countries such as Korea, compared to advanced countries.

This discussion can call for elaborate analysis on sectoral pattern of innovation, considering the change and difference of innovative environment. However, it can also call for differential business strategy and way to do innovate, which is proper considering the nature of innovative pattern in each industry for successful technological innovation in Korea. At the same time, it is confirmed that proper policy measure considering the differential pattern of technological innovation is needed.

This work can contribute in that it can be utilized for further research on sectoral innovation pattern in lateindustrializing countries and give a concrete ground for transformation of sectoral innovation pattern. However, it has also limitations in that this work should be combined with market-related indicators such as market expansion and exports and actual history of technological innovation, to be much plentiful discussion. Considering the importance of sectoral change (Pavitt, 1984; Malerba, 2006; Malerba \& Mani, 2009; Dolata, 2009), the dynamic evolution of sectoral pattern of change should be analyzed in the future. 


\section{Reference}

Breschi, S., Malerba, F., \& Orsenigo, L. (2000). Technological regimes and Schumpeterian patterns of innovation. The Economic Journal, 110(463), 388-410.

Breschi S., \& Malerba, F. (1997). Sectoral systems of innovations. In Edquist (ed.). Systems of innovation: technologies, Institutions and organizations, London, UK: Pinter Publishers/Cassell Academic.

Castellacci, F. (2008). Technological paradigms, regimes and trajectories: Manufacturing and service industries in a new taxonomy of sectoral patterns of innovation. Research Policy, 37(6-7), 978-994.

Chung, S. Y. (2001). Technological innovative regime in major industries, Seoul: STEPI.

Cohen, W., Goto, A., Nagata, A., Nelson, R., \& Walsh, J. (2002). R\&D spillovers, patents and the incentives to innovate in Japan and the United States. Research Policy, 31(8-9), 1349-67.

Coriat, B., Malerba, F. \& Montobbio, F. (2004). The international performance of European sectoral systems. in F. Malerba (ed.). Sectoral systems of innovation: concepts, issues and analyses of six major sectors in Europe, Cambridge, UK: Cambridge University Press.

De Jong, J. P. J \& Marsili, O. (2006). The fruit flies of innovations: A taxonomy of innovative small firms. Research Policy, 35(2), 213-229.

Dolata, U. (2009). Technological innovations and sectoral change: Transformative capacity, adaptability, patterns of change: An analytical framework. Research Policy, 38(6), 1066-1076.

Edquist, C. (1997). Systems of innovation approaches - their emergence and characteristics. In Edquist (ed.), Systems of innovation: technologies, Institutions and organizations. London, UK: Pinter Publishers/Cassell Academic.

Edquist, C. (2005). Systems of Innovation - perspectives and challenges, in Fagerberg, J., Mowery D. C. \& Nelson,

R. (eds.). The Oxford Handbook of Innovation. Oxford, UK: Oxford University Press.

Freel, M. (2003). Sectoral patterns of small firm innovation, networking and proximity. Research Policy, 32(5), 751770 .

Heidenreich, M. (2009). Innovation patterns and location of European low- and medium-technology industries. Research Policy, 38(3), 483-494.

Janne O., \& Frenz, M. (2006). Do firms patent to protect or transfer knowledge in support of their innovations? An analysis of the fourth UK Community Innovation Survey. DIME working paper.

Kim, Seok-Kwan. (2004). The innovative pattern and strategy for development in pharmaceutical industry. Seoul: STEPI (in Korean).

Kim, Seok-Kwan. (2006). The way to improve the innovation regime in pharmaceutical industry. Seoul.

Malerba, F., \& Mani, S. (2009). Sectoral systems of innovation and production in developing countries: an introduction. In Malerba F., \& Mani, S. (ed.). Sectoral Systems of Innovation and Production in Developing Countries. Massachusetts: Edward Elgar Publishing.

Malerba, F., \& Orsenigo, L. (1996). Schumpeterian patterns of innovation are technology-specific. Research Policy, 25(3), 451-478.

Malerba, F. (1997). Technological regimes and sectoral patterns of innovative activities. Industrial and corporate change, 6(1), 83-117.

Malerba, F. (2005). Sectoral systems - How and why innovation differs across sectors. In Fagerberg, J., Mowery D.

C. \& Nelson, R. (eds.). The Oxford Handbook of Innovation. Oxford, UK: Oxford University Press.

Malerba, F. (2006). Innovation and the evolution of industries. Journal of Evolutionary Economics, 16(1), 3-23.

Malerba F., \& Mani, S. (ed.). (2004) Sectoral Systems of Innovation and Production in Developing Countries. Massachusetts: Edward Elgar Publishing.

Park, Kyoo-Ho. (2003). Technological specialization and pattern for innovative activities in Korea. Research on technological innovation, 11(2), 11-25.

Pavitt, K. (1984). Sectoral patterns of technical change: Towards taxonomy and a theory. Research Policy, 13(6), 343-373.

Smith, Keith. (2005). Measuring Innovation. In Fagerberg, J., Mowery D. C., \& Nelson, R. (eds.). The Oxford Handbook of Innovation. Oxford, UK: Oxford University Press.

Song, Wi-Chin. (2000). Comparative analysis on technological innovative pattern by sectors. Seoul: STEPI.

STEPI. (2005). Korean Innovation survey 2005: Manufacturing sector. Seoul: STEPI.

Tidd, J., \& Bessant, J. (2009). Managing innovation: Integrating technological, market and organizational change. West Sussex: John Wiley \& Sons Ltd. 